\title{
Application of Enhanced BAC Process for Improving Drinking Water Treatment Efficiency
}

\author{
Heejong Son ${ }^{1, \oplus} \cdot$ Eun-Young Jung ${ }^{1 \odot} \cdot{\text { Hoon-Sik } \text { Yoom }^{1 \odot} \cdot \text { Sang-Goo Kim }}^{1 \odot} \cdot$ Sung Kyu Maeng ${ }^{2 \odot}$ \\ 'Water Quality Institute, Busan Water Authority \\ ${ }^{2}$ Department of Civil and Environmental Engineering, Sejong University
}

(Received May 12, 2020; Revised June 3, 2020; Accepted June 10, 2020)

Objectives: In this study, we compared the properties of the attached biofilm with the ability to remove biodegradable dissolved organic carbon (BDOC) in the conventional BAC (biologically activated carbon) process and the enhanced BAC process with phosphorus and hydrogen peroxide added. The enhanced BAC process was designed to increase the operational efficiency of the old $\mathrm{O}_{3} / \mathrm{BAC}$ process by evaluating the applicability of large-scale water treatment facilities located downstream of the Nakdong River.

Methods: The granular activated carbon which was used for 2 years in the $\mathrm{O}_{3} / \mathrm{BAC}$ process in the water treatment plant located downstream of the Nakdong River was used in this experiment. During the experiment period, the ozone dosage was fixed at $1 \mathrm{mg} \cdot \mathrm{O}_{3} / \mathrm{mg} \cdot$ DOC. Four acrylic columns with an inner diameter of $20 \mathrm{~cm}$ and a height of $250 \mathrm{~cm}$ were prepared. Empty bed contact time (EBCT) was fixed at 20 minutes and backwash was performed once a week. The four BAC columns are conventional BAC (control-BAC), enhanced BAC with hydrogen peroxide $\left(\mathrm{H}_{2} \mathrm{O}_{2}+\mathrm{BAC}\right)$, enhanced $\mathrm{BAC}$ with phosphorus $\left(\mathrm{PO}_{4}-\mathrm{P}+\mathrm{BAC}\right)$, and enhanced $\mathrm{BAC}$ with phosphorus and hydrogen peroxide together $\left(\mathrm{PO}_{4}-\mathrm{P}+\mathrm{H}_{2} \mathrm{O}_{2}+\mathrm{BAC}\right)$. In the case of enhanced $\mathrm{BAC}$ with $\mathrm{PO}_{4}-\mathrm{P}$ added, $\mathrm{PO}_{4}-\mathrm{P}$ was added with a concentration of $0.010 \mathrm{mg} / \mathrm{L}$ in the influent, and in $\mathrm{BAC}$ with $\mathrm{H}_{2} \mathrm{O}_{2}, \mathrm{H}_{2} \mathrm{O}_{2}$ was added with a concentration of $1 \mathrm{mg} / \mathrm{L}$ to the influent.

Results and Discussion: As a result of evaluating the recovery ability of the damaged biofilm, there was no difference in the biomass recovery rate in the $\mathrm{H}_{2} \mathrm{O}_{2}+\mathrm{BAC}$ compared to the control-BAC, but the biomass was rapidly recovered in the $\mathrm{PO}_{4}-\mathrm{P}+\mathrm{BAC}$. Considered the biomass and activity of the attached biofilm after the ability to remove organic substances reached a steady state, the biomass and activity in the entire filter layer of the $\mathrm{PO}_{4}-\mathrm{P}+\mathrm{BAC}$ increased by 20 to $86 \%$ and 7 to $14 \%$, respectively, compared to the control-BAC. In the $\mathrm{H}_{2} \mathrm{O}_{2}+\mathrm{BAC}$, only the activity increased by $3 \sim 11 \%$ and $\mathrm{In}$ the $\mathrm{PO}_{4}-\mathrm{P}+\mathrm{H}_{2} \mathrm{O}_{2}+\mathrm{BAC}$, biomass and activity were high, about 27 to $87 \%$ and 8 to $20 \%$, respectively. In the $\mathrm{H}_{2} \mathrm{O}_{2}+\mathrm{BAC}$, the BDOC removal rate was higher than the control-BAC by $20 \%$, and in the $\mathrm{PO}_{4}-\mathrm{P}+\mathrm{BAC}$, the $\mathrm{BDOC}$ removal rate increased by more than $100 \%$. Detached total cell counts (TCC) in the control-BAC effluent was $41.7 \times 10^{6}$ cells $/ \mathrm{mL}$ on average, and in the $\mathrm{H}_{2} \mathrm{O}_{2}+\mathrm{BAC}$, TCC was reduced by $49 \%$ compared to control-BAC and decreased by $67 \%$ and $85 \%$ in the $\mathrm{PO}_{4}-\mathrm{P}+\mathrm{BAC}$ and the $\mathrm{PO}_{4}-\mathrm{P}+\mathrm{H}_{2} \mathrm{O}_{2}+\mathrm{BAC}$ effluent. It means the biofilm of the enhanced BAC process was evaluated more stably than control-BAC.

Conclusions: The biomass and the activity of the attached biofilm in the BAC process, are one of the important factors that determine the ability to remove contaminants. The enhanced BAC process combined $\mathrm{PO}_{4}-\mathrm{P}$ with $\mathrm{H}_{2} \mathrm{O}_{2}$ was very effective in enhancing the biomass and the activity of the attached biofilm. The $\mathrm{PO}_{4}-\mathrm{P}$ added enhanced BAC was more effective in terms of biomass, BDOC removal rate, and biofilm stability than the $\mathrm{H}_{2} \mathrm{O}_{2}$ added enhanced BAC. The enhanced $\mathrm{BAC}$ combined $\mathrm{PO}_{4}-\mathrm{P}$ with $\mathrm{H}_{2} \mathrm{O}_{2}$ showed a slight increase additional efficiency compared to the $\mathrm{PO}_{4}-\mathrm{P}$ added $\mathrm{BAC}$.

Key Words: Biological Activated Carbon (BAC), Biofilm, Hydrogen Peroxide, Phosphate, Biodegradable Dissolved Organic Carbon (BDOC) 


\title{
연구논문
}

\section{정수처리 효율 향상을 위한 강화 생물활성탄 공정의 적용}

\author{
손희종 $^{1+\oplus} \cdot$ 정은영 $^{1 \odot} \cdot$ 염훈식 $^{1 \odot} \cdot$ 김상구 $^{1 \odot} \cdot$ 맹승규 $^{2 \odot}$ \\ ${ }^{1}$ 부산광역시 상수도사업본부 수질연구소 \\ ${ }^{2}$ 세종대학교 건설환경공학과
}

목적 : 본 연구에서는 기존 $\mathrm{BAC}$ (biological activated carbon) 공정과 인과 과산화수소를 투입하는 강화 $\mathrm{BAC}$ 공정 에서의 부착 생물막의 특성과 $\mathrm{BDOC}$ (biodegradable dissolved organic carbon) 제거능을 낙동강 하류에 위치한 pilot-plant에서 동일한 운전조건으로 비교하였다. 낙동강 하류에 위치한 대규모 정수장들의 노후화된 $\mathrm{O}_{3} / \mathrm{BAC}$ 공정 의 운전효율 증대를 위한 적용가능성을 평가하였다.

방법: 낙동강 하류에 위치한 정수장의 $\mathrm{O}_{3} / \mathrm{BAC}$ 공정에서 2 년 사용한 활성탄을 채집하여 사용하였다. 실험기간 동 안 후오존은 $1 \mathrm{mg} \cdot \mathrm{O}_{3} / \mathrm{mg} \cdot \mathrm{DOC}$ 로 고정하여 투입하였다. $\mathrm{BAC}$ 공정 시스템은 내경 $20 \mathrm{~cm}$, 높이 $250 \mathrm{~cm}$ 의 아크릴 컬럼 4 개를 사용하였다. 공탑체류시간은 20 분으로 고정하여 운전하였으며, 역세척은 주 1 회 실시하였다. 4 개의 $\mathrm{BAC}$ 컬럼들은 기존 $\mathrm{BAC}$ (control-BAC), 과산화수소를 투입한 강화 $\mathrm{BAC}\left(\mathrm{H}_{2} \mathrm{O}_{2}+\mathrm{BAC}\right)$, 인을 투입한 강화 $\mathrm{BAC}$ $\left(\mathrm{PO}_{4}-\mathrm{P}+\mathrm{BAC}\right)$ 및 인과 과산화수소를 함께 투입한 강화 $\mathrm{BAC}\left(\mathrm{PO}_{4}-\mathrm{P}+\mathrm{H}_{2} \mathrm{O}_{2}+\mathrm{BAC}\right)$ 이다. $\mathrm{PO}_{4}-\mathrm{P}$ 를 투입한 강화 $\mathrm{BAC}$ 의 경우 유입수에 $0.010 \mathrm{mg} / \mathrm{L}$ 의 농도로 $\mathrm{PO}_{4}-\mathrm{P}$ 를 추가로 보충하였으며, $\mathrm{H}_{2} \mathrm{O}_{2}$ 를 투입한 $\mathrm{BAC}$ 에서는 $\mathrm{H}_{2} \mathrm{O}_{2}$ 를 유입수 에 $1 \mathrm{mg} / \mathrm{L}$ 의 농도로 투입하였다.

결과 및 토의: 손상된 생물막의 회복능을 평가한 결과, $\mathrm{H}_{2} \mathrm{O}_{2}+\mathrm{BAC}$ 에서는 control-BAC와 비교하여 생체량 회복 율에 차이가 없었으나 $\mathrm{PO}_{4}-\mathrm{P}+\mathrm{BAC}$ 에서는 생체량이 빠르게 회복되었다. 유기물 제거능이 정상상태 도달한 이후 의 부착 생물막의 생체량과 활성도를 평가한 결과, $\mathrm{PO}_{4}-\mathrm{P}+\mathrm{BAC}$ 에서는 control- $\mathrm{BAC}$ 에 비해 전 여층에서 생체량 과 활성도가 각각 $20 \sim 86 \%$ 및 7 14\% 정도 증가하였으며, $\mathrm{H}_{2} \mathrm{O}_{2}+\mathrm{BAC}$ 에서는 활성도만 $3 \sim 11 \%$ 정도 증대되었다. $\mathrm{PO}_{4}-\mathrm{P}+\mathrm{H}_{2} \mathrm{O}_{2}+\mathrm{BAC}$ 에서는 생체량 및 활성도가 각각 $27 \sim 87 \%$ 및 $8 \sim 20 \%$ 정도 높게 나타났다. $\mathrm{H}_{2} \mathrm{O}_{2}+\mathrm{BAC}$ 에 서는 control-BAC에 비하여 $\mathrm{BDOC}$ 제거율이 $20 \%$ 정도 높게 나타났으며, $\mathrm{PO}_{4}-\mathrm{P}+\mathrm{BAC}$ 에서는 $\mathrm{BDOC}$ 제거율이 $100 \%$ 이상 증대되었다. Control-BAC 유출수 중의 탈리된 총 세균수(total cell counts, TCC)는 평균 $41.7 \times 10^{6}$ cells $/ \mathrm{mL}$ 이었으며, $\mathrm{H}_{2} \mathrm{O}_{2}+\mathrm{BAC}$ 에서는 control-BAC와 비교하여 $\mathrm{TCC}$ 가 $49 \%$ 정도 감소하였고, $\mathrm{PO}_{4}-\mathrm{P}+\mathrm{BAC}$ 와 $\mathrm{PO}_{4}-\mathrm{P}+\mathrm{H}_{2} \mathrm{O}_{2}+\mathrm{BAC}$ 에서는 각각 $67 \%$ 및 $85 \%$ 정도 감소하여 강화 $\mathrm{BAC}$ 공정의 생물막이 control-BAC에 비하여 더 안정적으로 평가되었다.

결론: 생물학적 처리공정의 일종인 $\mathrm{BAC}$ 공정에서 부착 생물막의 생체량과 활성도는 오염물질 제거능을 결정하는 중요 인자들 중 하나이다. $\mathrm{PO}_{4}-\mathrm{P}$ 와 $\mathrm{H}_{2} \mathrm{O}_{2}$ 를 투입한 강화 $\mathrm{BAC}$ 공정은 부착 생물막의 생체량과 활성도 증진에 매우 효과적이었다. $\mathrm{H}_{2} \mathrm{O}_{2}$ 에 비하여 $\mathrm{PO}_{4}-\mathrm{P}$ 를 투입한 강화 $\mathrm{BAC}$ 공정이 생물막의 생체량, $\mathrm{BDOC}$ 제거율 및 생물막의 안 정도 측면에서 더욱 효과적인 것으로 나타났다. $\mathrm{PO}_{4}-\mathrm{P}$ 만 투입한 경우에 비해 $\mathrm{PO}_{4}-\mathrm{P}$ 와 $\mathrm{H}_{2} \mathrm{O}_{2}$ 를 함께 투입한 강화 $\mathrm{BAC}$ 에서는 소폭으로 추가적인 효율 상승이 나타났다.

주제어: 생물활성탄, 생물막, 과산화수소, 인, 생분해 가능한 유기탄소

\section{1. 서론}

정수처리 공정에서 운영되고 있는 생물활성탄(biological activated carbon, $\mathrm{BAC)}$ 공정은 활성탄 표면과 세공에 다양 한 박테리아들이 자연적으로 서식하며 형성된 생물막에 의해 서 수중의 오염물질이 분해되어 제거되는 원리이다. ${ }^{1)} \mathrm{BAC}$ 에
형성된 활성 생물막은 수중에 잔존하는 다양한 오염물질들에 대해 우수한 제거능을 나타낸다. ${ }^{1)}$ 즉, 수중에 잔존하는 소독 부산물 전구물질을 비롯한 다양한 유기물질들, 이취 유발물 질, 잔류 의약물질, 개인위생용품 첨가물질, 내분비계 장애 물질, 암모니아성 질소, 용존 망간 등의 제거뿐만 아니라 관 망에서의 미생물 재성장능 저감 목적으로 적용되고 있다. ${ }^{1-4)}$ 
Table 1. Characteristics of post-ozonated water from Apr. to Dec. 2019.

\begin{tabular}{cccccc} 
& $\mathrm{pH}$ & $\mathrm{DOC}$ & $\mathrm{BDOC}$ & $\mathrm{PO}_{4}-\mathrm{P}$ & Temp \\
\cline { 2 - 5 } & $(-)$ & $(\mathrm{mg} / \mathrm{L})$ & $(\mathrm{mg} / \mathrm{L})$ & $(\mathrm{mg} / \mathrm{L})$ & $\left({ }^{\circ} \mathrm{C}\right)$ \\
Post-ozonated water & $6.8 \sim 7.8$ & $2.14 \sim 3.05$ & $0.32 \sim 0.83$ & $\mathrm{ND} 0.012$ & $(0.005)$ \\
\hline
\end{tabular}

$\mathrm{BAC}$ 공정의 제거효율에 영향을 미치는 인자들로는 활성 탄의 재질, 접촉시간, 역세척, 수온, 제한 영양물질 등 다양 하며, 이러한 영향인자들은 생물막의 특성에 영향을 미쳐 오염물질 제거능에 변화를 초래한다. ${ }^{2,3,5,6)}$

최근에는 $\mathrm{BAC}$ 공정의 효율증진 목적으로 강화 $\mathrm{BAC}$ 공 정에 대해 많은 연구가 진행 중이다. 강화 $\mathrm{BAC}$ 공정은 유 입수에 영양염 $(\mathrm{N}, \mathrm{P})$ 또는 과산화수소를 투입하여 $\mathrm{BAC}$ 에 형성된 생물막의 생체량과 활성을 증진시켜 $\mathrm{BAC}$ 공정의 제거효율 상승을 유도하는 원리이다. ${ }^{78)} \mathrm{BAC}$ 공정 유입수 중에 인(P) 농도가 충분하지 않은 경우, 생물막의 물리적 구 조와 형태가 변형되어 손실수두 증가와 오염물질 제거능이 감소된다. ${ }^{9)}$ 일반적으로 박테리아의 증식 및 생장에 필요한 $\mathrm{C}(\mathrm{BDOC}): \mathrm{N}\left(\mathrm{NH}_{4}-\mathrm{N}\right)$ : $\mathrm{P}\left(\mathrm{PO}_{4}-\mathrm{P}\right)$ 는 $100: 10$ : 1(화학량론 적인 질량농도 비 $=1 \mathrm{mg} / \mathrm{L}: 0.117 \mathrm{mg} / \mathrm{L}: 0.026 \mathrm{mg} / \mathrm{L})$ 로 보고 되고 있다. ${ }^{10)}$

또한, $\mathrm{BAC}$ 공정 강화목적으로 사용되는 과산화수소는 부 착 생물막으로의 추가적인 용존산소 공급원으로 작용할 뿐 만 아니라 생물막에 서식하는 특정 미생물 군집이 유기 화합 물의 산화를 촉진시키도록 과산화 효소 발현을 유도한다. ${ }^{11)}$ 이전의 연구결과들에서 저농도 $(1 \mathrm{mg} / \mathrm{L}$ 이하)로 투입된 과 산화수소는 생물막 내 활성 생체량의 생물학적 활성은 유지 시키면서 비활성 생체량에 대해서는 효과적으로 산화·제거 시키는 것으로 보고되고 있다. ${ }^{12,13)}$

정수장의 응집공정에서 사용되는 응집제들은 수중에 저 농도로 잔존하는 인(P)을 매우 효과적으로 제거하기 때문에 응집/침전 공정의 후단에 위치한 $\mathrm{BAC}$ 공정 유입수 중의 인 (P) 농도는 $0.01 \mathrm{mg} / \mathrm{L}$ 미만이다. ${ }^{14)}$ 후오존 처리수 중의 BDOC (biodegradable dissolved organic carbon) 농도가 0.38 $\mathrm{mg} / \mathrm{L}$ 보다 높을 경우 인 $(\mathrm{P})$ 이 제한인자로 작용하여 효율적 인 $\mathrm{BDOC}$ 제거능을 기대할 수 없기 때문에 인(P)의 보충이 필요하다.

본 연구에서는 낙동강 하류에 위치한 300 톤/일 규모의 pilot-plant에서 기존 $\mathrm{BAC}$ 공정과 인과 과산화수소를 투입 하는 강화 $\mathrm{BAC}$ 공정에서의 생물막 특성과 $\mathrm{BDOC}$ 제거능 을 동일한 운전조건에서 비교·평가하였다. 특히, (1) 생물막 손상에 따른 부착 생물막 회복능, (2) 부착 생물막의 생체량 과 활성도, (3) $\mathrm{BDOC}$ 제거능, (4) 생물막의 안정도를 비교. 평가하여 낙동강 하류에 위치한 대규모 정수장들의 노후화 된 $\mathrm{O}_{3} / \mathrm{BAC}$ 공정의 운전효율 증대를 위한 적용가능성을 평 가하였다.

\section{2. 실험재료 및 방법}

\section{1. 실험재료}

\subsection{1. $\mathrm{BAC}$ 용 활성탄}

$\mathrm{BAC}$ 용 입상활성탄은 낙동강 하류에 위치한 정수장의 오 존/BAC 공정에서 2 년 정도 사용한 것으로 $\mathrm{BAC}$ 여과지 표 층 $10 \mathrm{~cm}$ 이내에서 채집하였다. 채집한 $\mathrm{BAC}$ 를 수돗물로 여 러 번 세척한 후 수돗물에 침지시켜 7일간 수돗물을 매일 2 회 갈아주면서 $\mathrm{BAC}$ 부착 생물막의 생체량과 활성도를 인위 적으로 저하시켰다. 이는 $\mathrm{BAC}$ 강화 조건에 따른 운전 초기 의 생물막 회복능을 평가하기 위함으로 부착 생물막의 생체 량과 활성도 저하과정을 거친 후의 생물막의 생체량 $(\mathrm{n}=3)$ 과 활성도 $(\mathrm{n}=3)$ 는 각각 $1.47 \pm 0.29 \mu \mathrm{g} \cdot \mathrm{ATP} / \mathrm{g} \cdot \mathrm{GAC}$ 및 $1.13 \pm 0.24$ $\mathrm{mg} \cdot \mathrm{C} / \mathrm{m}^{3} \cdot \mathrm{h}$ 이었다.

\subsection{2. 후오존 처리수 성상}

$\mathrm{BAC}$ 공정으로 유입되는 후오존 처리수는 300 톤/일 처리 규모 pilot-plant의 후오존 처리수를 사용하였다. 실험기간 (2019년 4월 2019년 12월) 동안의 후오존 투입농도는 BDOC 생성율이 높은 것으로 보고된 오존 투입농도인 $1 \mathrm{mg} \cdot \mathrm{O}_{3} / \mathrm{mg} \cdot$ $\mathrm{DOC}$ 로 고정하여 운전하였으며 ${ }^{15)}$, 1 주일에 3 번 후오존 공정 으로 유입되는 모래여과수의 DOC 농도를 측정하여 후오존 투입농도를 조절하였다. 후오존 공정에서의 체류시간은 15 분이며, 후오존 공정 후단에 저류조가 있어 잔류오존이 완전 히 소모된 후 각각의 $\mathrm{BAC}$ 컬럼들로 후오존 처리수가 공급된 다. 실험기간 동안의 후오존 처리수 성상을 Table1에 나타내 었다. DOC 농도범위는 $2.14 \sim 3.05 \mathrm{mg} / \mathrm{L}$, 평균 $2.59 \mathrm{mg} / \mathrm{L}$ 였으 며, $\mathrm{BDOC}$ 농도범위는 $0.32 \sim 0.83 \mathrm{mg} / \mathrm{L}$, 평균 $0.63 \mathrm{mg} / \mathrm{L}$ 였다. 수온은 $7 \sim 26^{\circ} \mathrm{C}$ 였다.

\subsubsection{BAC 컬럼 시스템 및 운전}

본 실험에 사용된 $\mathrm{BAC}$ 컬럼 시스템은 Fig.1에서 볼 수 있듯이 내경 $20 \mathrm{~cm}$, 높이 $250 \mathrm{~cm}$ 의 아크릴 컬럼 4 개를 사 용하였으며, 후오존 저류조에서 이송된 후오존 처리수가 각 각의 $\mathrm{BAC}$ 컬럼들 상부로 공급되는 하향류 방식으로 운전 하였다. 각각의 $\mathrm{BAC}$ 컬럼에 층고 $100 \mathrm{~cm}$ 가 되도록 $\mathrm{BAC}$ 를 충진하여 공탑체류시간(empty bed contact time, EBCT) 20 분으로 고정하여 운전하였다. 역세척은 공세 3 분 및 수세 10 분의 조건으로 주 1 회 실시하였다.

4 개의 $\mathrm{BAC}$ 컬럼들은 인 $\left(\mathrm{PO}_{4}-\mathrm{P}\right)$ 과 과산화수소 $\left(\mathrm{H}_{2} \mathrm{O}_{2}\right)$ 를 투 

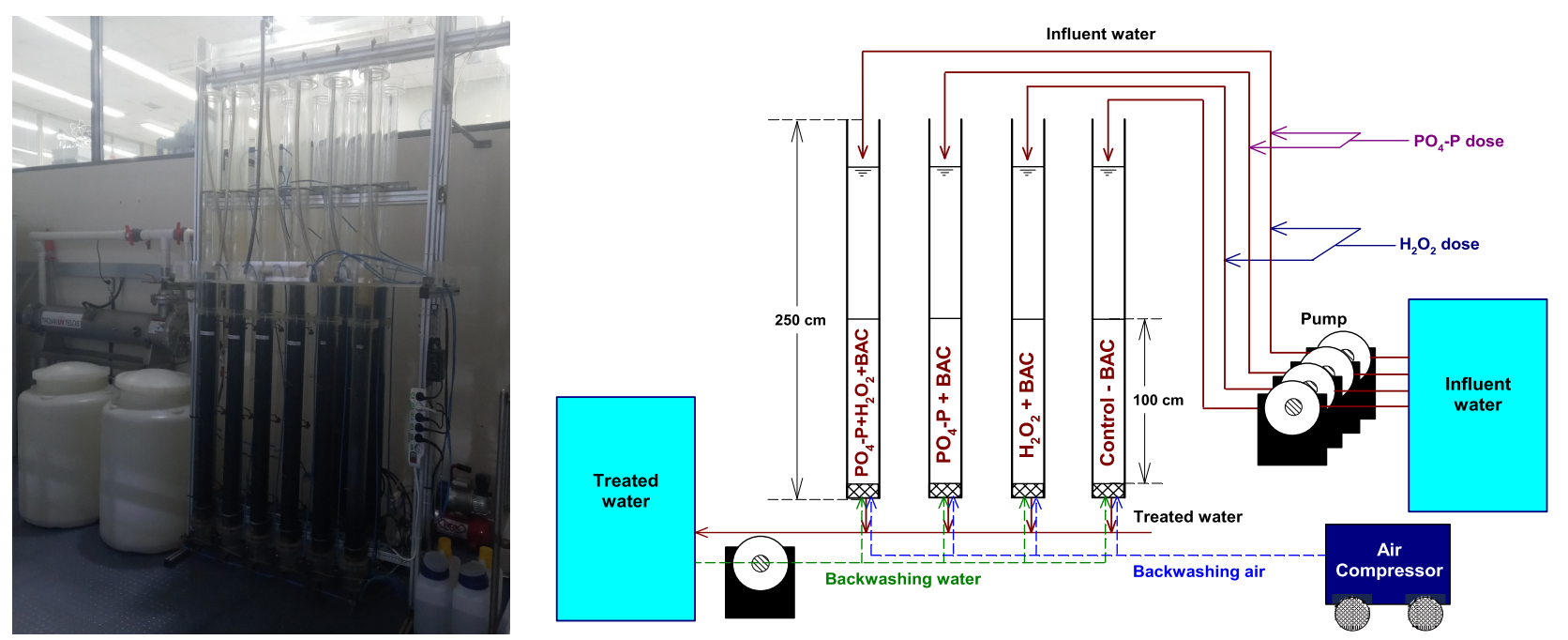

Fig. 1. Photograph and schematic diagram of BAC column system.

입하지 않는 기존 $\mathrm{BAC}$ 컬럼(control-BAC), $\mathrm{H}_{2} \mathrm{O}_{2}$ 를 투입 하는 강화 $\mathrm{BAC}$ 컬럼 $\left(\mathrm{H}_{2} \mathrm{O}_{2}+\mathrm{BAC}\right), \mathrm{PO}_{4}-\mathrm{P}$ 를 투입하는 강화 $\mathrm{BAC}$ 컬럼 $\left(\mathrm{PO}_{4}-\mathrm{P}+\mathrm{BAC}\right)$ 및 $\mathrm{PO}_{4}-\mathrm{P}$ 와 $\mathrm{H}_{2} \mathrm{O}_{2}$ 를 함께 투입하는 강화 $\mathrm{BAC}$ 컬럼 $\left(\mathrm{PO}_{4}-\mathrm{P}+\mathrm{H}_{2} \mathrm{O}_{2}+\mathrm{BAC}\right)$ 이며, 병렬로 설치하여 운전하였다. $\mathrm{PO}_{4}-\mathrm{P}$ 와 $\mathrm{H}_{2} \mathrm{O}_{2}$ 는 각각의 $\mathrm{BAC}$ 컬럼으로 이송되 는 후오존 처리수 공급라인에 정밀유량 펌프(Masterflex ${ }^{\circledR}$ $\mathrm{L} / \mathrm{S}^{\circledR}$, Cole-Parmer, USA)를 설치하여 각각의 강화 BAC 컬 럼들의 운전조건에 맞춰 인과 과산화수소를 투입하였다.

$\mathrm{PO}_{4}-\mathrm{P}$ 를 투입하는 강화 $\mathrm{BAC}$ 컬럼들에는 유입수에 추가 적으로 $0.010 \mathrm{mg} / \mathrm{L}$ 의 $\mathrm{PO}_{4}-\mathrm{P}$ 가 더 공급되도록 $\mathrm{PO}_{4}-\mathrm{P}$ 를 투입 하였다. 이전의 연구들에서는 응집/침전/모래여과 공정에서 제거되지 않고 후단으로 유입된 수산화알루미늄에 의한 $\mathrm{PO}_{4}-\mathrm{P}$ 흡착 방지와 $\mathrm{BAC}$ 생물막으로의 일관된 $\mathrm{PO}_{4}-\mathrm{P}$ 의 전 달을 위해 $\mathrm{BAC}$ 공정에서 필요한 $\mathrm{PO}_{4}-\mathrm{P}$ 의 요구량의 2 배 이 상의 $\mathrm{PO}_{4}-\mathrm{P}$ 를 투입하였다. ${ }^{7)}$ 그러나 본 연구에서는 과량으로 투입된 $\mathrm{PO}_{4}-\mathrm{P}$ 는 배·급수관망으로의 유출되어 미생물 재성 장을 유발할 가능성 때문에 실제 정수장 적용에 한계가 있 어 낙동강 하류에 위치한 정수장의 후오존 처리수 중에 함 유된 $\mathrm{BDOC}$ 농도(최대 $0.55 \mathrm{mg} / \mathrm{L}$ )를 기준으로 $0.010 \mathrm{mg} / \mathrm{L}$ 를 투입하였다. 실험기간 동안 후오존 처리수의 $\mathrm{PO}_{4} \mathrm{P}$ 농도는 평균 $0.005 \mathrm{mg} / \mathrm{L}$ 로 정도로 나타났다.

$\mathrm{H}_{2} \mathrm{O}_{2}$ 를 투입하는 강화 $\mathrm{BAC}$ 컬럼들에는 $\mathrm{BAC}$ 컬럼으로 유 입되는 $\mathrm{H}_{2} \mathrm{O}_{2}$ 농도가 $1 \mathrm{mg} / \mathrm{L}$ 가 되도록 투입하였다. $\mathrm{PO}_{4}-\mathrm{P}$ 와 $\mathrm{H}_{2} \mathrm{O}_{2}$ 는 각각 $85 \%$ 인산 용액(Sigma-aldrich, USA)과 $30 \%$ 과산화수소 용액(Sigma-aldrich, USA)을 희석하여 사용하 였다.

\section{2. 실험방법}

\subsubsection{BAC 부착 박테리아 생체량 및 활성도}

부착 박테리아의 생체량은 ATP 농도를 측정하여 평가하였 다. 활성탄 습중량 $200 \mathrm{mg}$ 을 채집하여 Velten 등이 제시한
방법 ${ }^{16)}$ 으로 전처리한 후 luminometer (Victor3, PerkinElmer, USA)를 이용하여 분석하였다.

부착 박테리아의 활성도는 Son 등의 연구 ${ }^{17}$ 에서 사용된 방법인 ${ }^{3} \mathrm{H}$-thymidine이 DNA에 흡수되는 양을 측정하는 방 법을 이용하였다. 활성탄 습중량 $1 \mathrm{~g}$ 을 채집하여 전처리한 후 liquid scintillation analyzer (PerkinElmer, Quantulus 1220, USA)로 분석하였으며, 얻어진 DPM (disintergrate per minute) 값으로부터 박테리아에 결합된 thymidine의 양을 계산하여 활성탄 $\mathrm{g}$ 당 생체량으로 환산하였다.

\subsection{2. 총 박테리아 개체수 분석}

부착 생물막의 안정도 평가를 위해 각각의 $\mathrm{BAC}$ 컬럼 처 리수 중에 함유된 총 박테리아 개체수(total cell count, TCC) 를 flow cytometer (CytoFLEX, Beckman Coulter, USA)를 사용하여 분석하였다. 입자상 물질 제거를 위해 $\mathrm{GF} / \mathrm{C}$ 여지 (Whatman, USA)로 여과한 시료 $300 \mu \mathrm{L}$ 에 SYBR 염색약 $\left(\mathrm{SYBR}^{\circledR}\right.$ Gold nucleic acid gel stain, Invitrogen, USA) 10 $\mu \mathrm{L}$ 와 $50 \mu \mathrm{g} / \mathrm{mL}$ 농도로 조제한 PI 염색약(propidium iodide, Invitrogen, USA) $10 \mu \mathrm{L}$ 를 첨가하여 잘 혼합한 다음 10 분간 정치반응 후 flow cytometer로 측정하였다. SYBR 시약은 활성 세포의 두 가닥 DNA 사이에 염색되어 형광 발색되며, PI 시약은 비활성 세포의 핵에 염색된다.

\subsection{3. $\mathrm{BDOC}$ 분석}

유입수와 처리수에 함유된 생물분해 가능한 유기탄소 (biodegradable dissolved organic carbon, BDOC) 농도는 Servais 등이 제안한 방법을 이용하였다. ${ }^{18)}$ 시료수 $200 \mathrm{~mL}$ 를 공극크기 $0.2 \mu \mathrm{m}$ 인 멤브레인 필터(Millipore, USA)로 여 과한 시료에 $\mathrm{BAC}$ 에서 탈리시킨 부착 박테리아 탈리액을 공극크기 $2 \mu \mathrm{m}$ 인 멤브레인 필터(Millipore, USA)로 여과하 여 여액 $2 \mathrm{~mL}$ 를 식종하였다. 유기탄소가 박테리아 대사의 


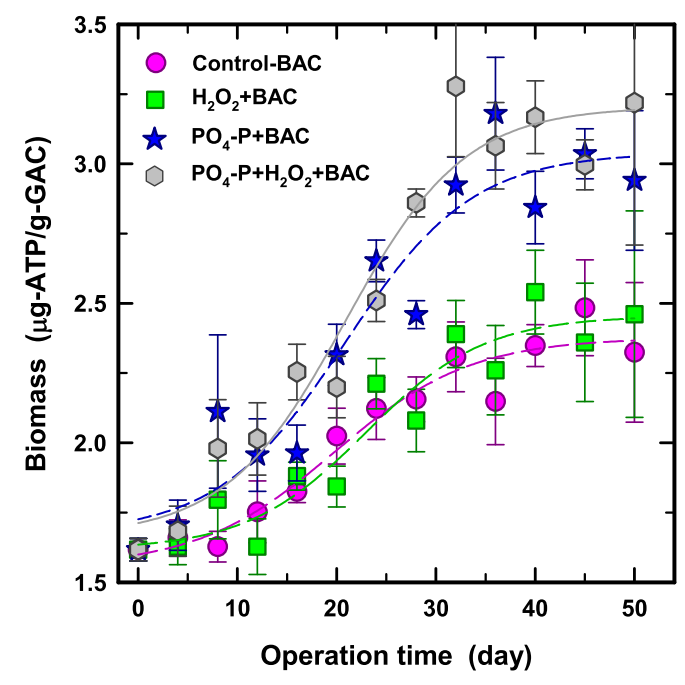

Fig. 2. Changes of biomass concentration of the top layer ( -5 $\mathrm{cm}$ ) of the BAC columns with increasing operation time $(n=3)$.

제한인자로 작용하도록 무기 영양염 농축 cocktail ${ }^{19)}$ 을 주입 하였다. $20^{\circ} \mathrm{C}$ 항온배양기에서 28 일간 배양하여 배양 전·후 의 $\mathrm{DOC}$ 농도 차로 $\mathrm{BDOC}$ 농도를 산정하였다. $\mathrm{DOC}$ 농도는 총유기탄소 측정기(Sievers M9, GE, USA)를 이용하여 분석 하였다.

\subsection{4. $\mathrm{PO}_{4}-\mathrm{P}$ 분석}

$\mathrm{BAC}$ 컬럼 유입수와 유출수 중의 $\mathrm{PO}_{4}-\mathrm{P}$ 농도분석은 전자동 수질분석기(QuAAtro39, BL Tech, Germany)를 이용하였으며, 시료수 중의 입자상 물질 제거를 위하여 $\mathrm{GF} / \mathrm{C}$ 여지(Whatman, USA)로 여과한 후 분석하였다. $\mathrm{PO}_{4}-\mathrm{P}$ 의 정량한계는 0.001 $\mathrm{mg} / \mathrm{L}$ 이다.

\section{3. 결과 및 고찰}

\section{1. 운전초기의 부착 생물막 특성 평가}

정수장에서 채집한 $\mathrm{BAC}$ 의 생물막 생체량을 인위적으로 저하시켜 컬럼들에 충진 후 각각의 강화 조건에 따라 운전 기간 증가에 따른 BAC 상층부의 생물막 생체량(ATP 농도) 변화를 평가한 것을 Fig. 2에 나타내었다. Fig. 2에서 볼 수 있듯이 기존 $\mathrm{BAC}$ (control-BAC)와 3 가지 강화 조건을 적용 한 $\mathrm{BAC}$ 컬럼들에서 운전 기간의 증가에 따라 생물막 생체 량이 증대되었으며, 특히, $\mathrm{PO}_{4}-\mathrm{P}$ 를 투입한 $\mathrm{PO}_{4}-\mathrm{P}+\mathrm{BAC}$ 와 $\mathrm{PO}_{4}-\mathrm{P}+\mathrm{H}_{2} \mathrm{O}_{2}+\mathrm{BAC}$ 에서 생물막의 생체량 증대가 두드러졌다.

Control-BAC와 $\mathrm{H}_{2} \mathrm{O}_{2}+\mathrm{BAC}$ 에서는 운전 초기에 비하여 각각 0.70 와 $0.84 \mu \mathrm{g} \cdot \mathrm{ATP} / \mathrm{g} \cdot \mathrm{GAC}$ 가 증가하였으며, 증가 율은 대략 $43 \%$ 와 $52 \%$ 로 나타났다. 또한, $\mathrm{PO}_{4}-\mathrm{P}+\mathrm{BAC}$ 와 $\mathrm{PO}_{4}-\mathrm{P}+\mathrm{H}_{2} \mathrm{O}_{2}+\mathrm{BAC}$ 의 경우는 각각 1.32 와 $1.60 \mu \mathrm{g} \cdot \mathrm{ATP} / \mathrm{g} \cdot$ $\mathrm{GAC}$ 가 증가하여 단기간에 생물막의 생체량이 $81 \%$ 와 $99 \%$ 정도 증가하였다.

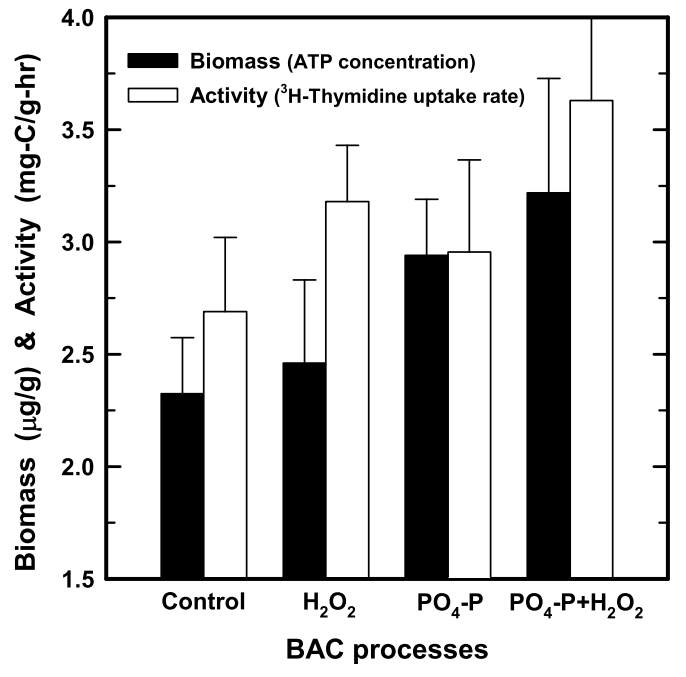

Fig. 3. Changes of biomass and microbial activity in biofilm collected from the top layer $(\sim-5 \mathrm{~cm})$ of $B A C$ columns under various enhancement conditions after 50 days of operation $(n=3)$.

50 일 운전 이후에 control-BAC와 강화 $\mathrm{BAC}$ 컬럼들의 부 착 생물막 생체량을 비교해보면 control- $\mathrm{BAC}$ 의 $2.32 \mu \mathrm{g}$. $\mathrm{ATP} / \mathrm{g} \cdot \mathrm{GAC}$ 에 비하여 $\mathrm{H}_{2} \mathrm{O}_{2}+\mathrm{BAC}, \mathrm{PO}_{4}-\mathrm{P}+\mathrm{BAC}$ 및 $\mathrm{PO}_{4}-\mathrm{P}+$ $\mathrm{H}_{2} \mathrm{O}_{2}+\mathrm{BAC}$ 에서는 각각 $2.46,2.94$ 및 $3.22 \mu \mathrm{g} \cdot \mathrm{ATP} / \mathrm{g} \cdot \mathrm{GAC}$ 의 ATP 농도를 나타내어 대략 $6 \%, 27 \%$ 및 $39 \%$ 정도 더 높 은 생체량을 보였다.

여러 연구결과들에서 유입수에 $\mathrm{PO}_{4}-\mathrm{P}$ 를 강화(보충)시킨 경우, 여재 부착 생물막의 생체량이 증가한 것으로 보고하 고 있으며 ${ }^{14,20)}$, Lauderdale 등의 연구결과 ${ }^{7)}$ 에서도 유입수에 $\mathrm{PO}_{4}-\mathrm{P}$ 농도를 강화시켜 운전한 biofilter에서 대조군 biofilter 에 비해 부착 생물막의 ATP 농도가 $30 \%$ 정도 더 높은 것으 로 보고하고 있다. $\mathrm{BAC}$ 와 같은 생물여과(biofiltration) 공정 에서 유입수 중에 $\mathrm{PO}_{4}-\mathrm{P}$ 가 제한적인 경우, $\mathrm{PO}_{4}-\mathrm{P}$ 의 보충(강 화)에 의해 $\mathrm{BAC}$ 부착 박테리아의 기질대사 및 세포합성 능 력을 향상시켜 생물막의 생체량 및 활성도가 증대되며, 이 것은 결국 수중의 오염물질 제거능의 향상으로 연결된다.

운전 시작 50 일 이후에 각각의 $\mathrm{BAC}$ 컬럼 상층부에 형성된 생물막의 생체량과 활성도 평가 결과를 Fig. 3에 나타내었다. 생체량과 유사하게 활성도의 경우도 기존 $\mathrm{BAC}$ (control-BAC) 에 비하여 $\mathrm{H}_{2} \mathrm{O}_{2}$ 와 $\mathrm{PO}_{4}-\mathrm{P}$ 를 투입한 강화 $\mathrm{BAC}$ 컬럼들에서 높 게 나타났다.

활성도의 경우, control-BAC의 $2.69 \mathrm{mg} \cdot \mathrm{C} / \mathrm{g} \cdot \mathrm{h}$ 에 비해 $\mathrm{H}_{2} \mathrm{O}_{2}+\mathrm{BAC}, \mathrm{PO}_{4}-\mathrm{P}+\mathrm{BAC}$ 및 $\mathrm{PO}_{4}-\mathrm{P}+\mathrm{H}_{2} \mathrm{O}_{2}+\mathrm{BAC}$ 에서는 각 각 $3.18,2.96$ 및 $3.63 \mathrm{mg} \cdot \mathrm{C} / \mathrm{g} \cdot \mathrm{h}$ 로 나타나 대략 $18 \%, 10 \%$ 및 $35 \%$ 정도 증가하였으며, 특히, $\mathrm{H}_{2} \mathrm{O}_{2}$ 를 투입한 $\mathrm{BAC}$ $\left(\mathrm{H}_{2} \mathrm{O}_{2}+\mathrm{BAC}\right.$ 와 $\left.\mathrm{PO}_{4}-\mathrm{P}+\mathrm{H}_{2} \mathrm{O}_{2}+\mathrm{BAC}\right)$ 에서의 활성도 증가가 뚜렷하게 나타났다. Fig. 2와 Fig. 3에서 살펴본 바와 같이 $\mathrm{BAC}$ 강화 목적으로 투입되는 인( $\left.\mathrm{PO}_{4}-\mathrm{P}\right)$ 은 부착 생물막의 생체량 증대에 주로 기여하는 반면, 과산화수소 $\left(\mathrm{H}_{2} \mathrm{O}_{2}\right)$ 의 경 
Table 2. Biofilm characteristics under steady state according to enhancement conditions of BAC process (Jul. Dec. 2019) ( $n=12$ ).

\begin{tabular}{|c|c|c|c|c|c|c|c|c|c|c|c|c|}
\hline \multirow{3}{*}{$\begin{array}{c}\text { BAC processes } \\
\text { Bed depth }\end{array}$} & \multicolumn{3}{|c|}{ Conventional-BAC } & \multicolumn{9}{|c|}{ Enhanced-BAC } \\
\hline & \multicolumn{3}{|c|}{ Control-BAC } & \multicolumn{3}{|c|}{$\mathrm{H}_{2} \mathrm{O}_{2}+\mathrm{BAC}$} & \multicolumn{3}{|c|}{$\mathrm{PO}_{4}-\mathrm{P}+\mathrm{BAC}$} & \multicolumn{3}{|c|}{$\mathrm{PO}_{4}-\mathrm{P}+\mathrm{H}_{2} \mathrm{O}_{2}+\mathrm{BAC}$} \\
\hline & $-5 \mathrm{~cm}$ & $-50 \mathrm{~cm}$ & $-90 \mathrm{~cm}$ & $-5 \mathrm{~cm}$ & $-50 \mathrm{~cm}$ & $-90 \mathrm{~cm}$ & $-5 \mathrm{~cm}$ & $-50 \mathrm{~cm}$ & $-90 \mathrm{~cm}$ & $-5 \mathrm{~cm}$ & $-50 \mathrm{~cm}$ & $-90 \mathrm{~cm}$ \\
\hline $\begin{array}{c}\text { Biomass } \\
(\mu \mathrm{g} \cdot \mathrm{ATP} / \mathrm{g} \cdot \mathrm{GAC})\end{array}$ & $\begin{array}{c}2.68 \\
( \pm 0.45)\end{array}$ & $\begin{array}{c}1.18 \\
( \pm 0.32)\end{array}$ & $\begin{array}{c}0.66 \\
( \pm 0.25)\end{array}$ & $\begin{array}{c}2.70 \\
( \pm 0.51)\end{array}$ & $\begin{array}{c}1.21 \\
( \pm 035)\end{array}$ & $\begin{array}{c}0.65 \\
( \pm 0.22)\end{array}$ & $\begin{array}{c}3.22 \\
( \pm 0.45)\end{array}$ & $\begin{array}{c}2.19 \\
( \pm 0.41)\end{array}$ & $\begin{array}{c}1.06 \\
( \pm 0.29)\end{array}$ & $\begin{array}{c}3.41 \\
( \pm 0.42)\end{array}$ & $\begin{array}{c}2.21 \\
( \pm 0.38)\end{array}$ & $\begin{array}{c}1.09 \\
( \pm 0.27)\end{array}$ \\
\hline $\begin{array}{c}\text { Activity } \\
(\mathrm{mg} \cdot \mathrm{C} / \mathrm{g} \cdot \mathrm{hr})\end{array}$ & $\begin{array}{c}2.80 \\
( \pm 0.34)\end{array}$ & $\begin{array}{c}2.32 \\
( \pm 0.39)\end{array}$ & $\begin{array}{c}2.24 \\
( \pm 0.31)\end{array}$ & $\begin{array}{c}3.11 \\
( \pm 0.31)\end{array}$ & $\begin{array}{c}2.52 \\
( \pm 0.31)\end{array}$ & $\begin{array}{c}2.31 \\
( \pm 0.35)\end{array}$ & $\begin{array}{c}3.05 \\
( \pm 0.25)\end{array}$ & $\begin{array}{c}2.65 \\
( \pm 0.22)\end{array}$ & $\begin{array}{c}2.39 \\
( \pm 0.20)\end{array}$ & $\begin{array}{c}3.37 \\
( \pm 0.23)\end{array}$ & $\begin{array}{c}2.75 \\
( \pm 0.27)\end{array}$ & $\begin{array}{c}2.41 \\
( \pm 0.19)\end{array}$ \\
\hline
\end{tabular}

우는 생물막의 활성도 증대에 기여하는 것으로 평가되었다.

$\mathrm{H}_{2} \mathrm{O}_{2}$ 는 $\mathrm{PO}_{4}-\mathrm{P}$ 와 같이 무기 영양염으로 작용하지는 않지 만 생물막으로의 추가적인 용존산소 공급뿐만 아니라 생물 막에 서식하는 특정 미생물 군집이 유기 화합물의 산화를 촉 진시키는 과산화 효소를 발현하도록 유도한다. ${ }^{11)}$ 또한, 이전 의 연구결과들 ${ }^{12,13)}$ 에서 저농도 $\left(1 \mathrm{mg} / \mathrm{L}\right.$ 이하)로 투입된 $\mathrm{H}_{2} \mathrm{O}_{2}$ 는 생물막 내 활성 박테리아의 생물학적 활성을 유지시키면 서 비활성 박테리아를 효과적으로 산화·제거하는 것으로 보고되었다.

\section{2. 유기물질 제거능 평가}

유기물질 제거율이 정상상태에 도달한 이후의 생물막 특 성과 유기물질 제거능을 평가한 것을 Table 2 및 Fig. 4와

Fig. 5 에 나타내었다. 이전의 연구결과들에서 biofilter의 유 기물질 제거율이 정상상태에 도달하는 기간은 20 일부터 16 개월까지로 상당한 차이를 나타내고 있다. ${ }^{21)}$ 이는 유입수 중의 BOM (biodegradable organic matter) 농도, 수온, 여재 특성 및 역세척 주기와 같은 다양한 인자들이 영향을 미치 기 때문이며 ${ }^{2)}$, 본 연구에서는 운전 시작 후 3 개월 정도 경 과한 시점에서 각각의 $\mathrm{BAC}$ 컬럼들의 유기물질 제거율과 생물막 생체량이 정상상태에 도달하였다. 정상상태 도달 이 후 6 개월 동안 월 2 회씩 총 12 회 분석한 각각의 $\mathrm{BAC}$ 컬럼 들의 여층 깊이별 $(-5 \sim-90 \mathrm{~cm})$ 생물막 생체량과 활성도 변 화에 대한 평균값을 Table 2에 나타내었다.

Table 2에서 볼 수 있듯이 $\mathrm{PO}_{4}-\mathrm{P}$ 를 투입한 강화 $\mathrm{BAC}\left(\mathrm{PO}_{4}-\mathrm{P}\right.$ $+\mathrm{BAC})$ 에서는 전 여층 $(-5 \sim-90 \mathrm{~cm}$ )에서 기존 $\mathrm{BAC}$ (control$\mathrm{BAC}$ )에 비해 생물막의 생체량이 $20 \sim 86 \%$ 정도 높게 나타 났고, 활성도의 경우에는 7 14\% 정도 증가하여 생체량에 비해서는 낮은 증가율을 보였다. 또한, $\mathrm{H}_{2} \mathrm{O}_{2}$ 를 투입한 강화 $\mathrm{BAC}\left(\mathrm{H}_{2} \mathrm{O}_{2}+\mathrm{BAC}\right)$ 에서는 전 여층에서 생체량과 활성도가 control-BAC와 비교하여 각각 -2 3\% 및 3 11\% 정도 높게 나타나 $\mathrm{H}_{2} \mathrm{O}_{2}$ 투입에 의해 생체량은 증가하지 않은 반면 활성 도는 증대되었다. $\mathrm{PO}_{4}-\mathrm{P}$ 와 $\mathrm{H}_{2} \mathrm{O}_{2}$ 를 함께 투입한 강화 $\mathrm{BAC}$ $\left(\mathrm{PO}_{4}-\mathrm{P}+\mathrm{H}_{2} \mathrm{O}_{2}+\mathrm{BAC}\right)$ 의 경우는 control-BAC에 비하여 생체량 과 활성도가 각각 $27 \sim 87 \%$ 및 $8 \sim 20 \%$ 정도 높게 나타났다.

또한, control-BAC에 비해 $\mathrm{PO}_{4}-\mathrm{P}$ 를 투입한 강화 $\mathrm{BAC}$ 에서 는 중·하층부의 생물막 생체량 증가율이 매우 높게 나타났 다. 이러한 결과는 control-BAC의 경우 여층 상부에서의 높
은 $\mathrm{PO}_{4}-\mathrm{P}$ 요구량으로 인해 유입수에 함유된 $\mathrm{PO}_{4}-\mathrm{P}$ 농도만 으로는 중·하층부 생물막의 $\mathrm{PO}_{4}-\mathrm{P}$ 요구량을 만족시키지 못 한다는 것을 보여준다. 그리고 $\mathrm{H}_{2} \mathrm{O}_{2}$ 를 투입한 강화 $\mathrm{BAC}$ 의 경우에는 전 여층에서 소폭으로 생물막 활성도가 증가하였 다. $\mathrm{H}_{2} \mathrm{O}_{2}$ 는 용존산소 공급, 활성 박테리아 활성 증대, 유기 물 산화 촉진 효소(과산화 효소) 발현을 유도하는 역할뿐만 아니라 비활성 박테리아 산화·제거 역할을 한다. ${ }^{11-13)}$ 본 연 구에서는 처리수를 포함하여 여층 중·하층으로 유입되는 $\mathrm{H}_{2} \mathrm{O}_{2}$ 의 농도는 모니터링하지는 않았으나 $\mathrm{BAC}$ 컬럼으로 유 입된 $\mathrm{H}_{2} \mathrm{O}_{2}$ 의 대부분이 상층부에서 물과 용존산소로 분해되 었을 것으로 판단하며, 중·하층부로의 $\mathrm{H}_{2} \mathrm{O}_{2}$ 유입이 없는 상 황에서 부착 생물막의 활성도가 증진된 것은 용존산소 농도 증가와 상층부의 비활성 생체량의 산화·제거시 발생되는 유기탄소와 미량 영양염이 중·하층부로 유입되어 생물막의 활성도 증진에 영향을 미친 것으로 판단하였으며, 이에 대 한 추가적인 연구가 필요한 것으로 나타났다.

정상상태 도달 이후, $\mathrm{BAC}$ 공정 유입수 중의 $\mathrm{PO}_{4} \mathrm{-P}$ 농도 와 각각의 $\mathrm{BAC}$ 컬럼들에서 제거된 $\mathrm{BDOC}$ 농도와의 상관성 을 평가한 결과를 Fig.4에 나타내었다. 실험기간 동안 후오 존 처리수 중에 함유된 $\mathrm{PO}_{4}-\mathrm{P}$ 농도와 $\mathrm{BDOC}$ 농도는 각각 $\mathrm{ND} \sim 0.012 \mathrm{mg} / \mathrm{L}$ (평균: $0.0049 \mathrm{mg} / \mathrm{L}$ ) 및 $0.32 \sim 0.83 \mathrm{mg} / \mathrm{L}$ (평 균: $0.63 \mathrm{mg} / \mathrm{L}$ )였다.

Fig. 4에서 볼 수 있듯이 $\mathrm{BAC}$ 컬럼으로 공급된 $\mathrm{PO}_{4}-\mathrm{P}$ 농 도와 $\mathrm{BAC}$ 컬럼에서 제거된 $\mathrm{BDOC}$ 농도와는 높은 상관성 $\left(r^{2}=0.868\right)$ 을 나타내었고, 유입수에 $\mathrm{PO}_{4}-\mathrm{P}$ 를 강화한 경우에 추가적인 $\mathrm{BDOC}$ 의 제거가 유발되었다. 즉, $\mathrm{PO}_{4}-\mathrm{P}$ 를 투입하 지 않은 $\mathrm{BAC}$ (control-BAC와 $\mathrm{H}_{2} \mathrm{O}_{2}+\mathrm{BAC}$ )에서의 $\mathrm{PO}_{4}-\mathrm{P}$ 농 도범위는 $\mathrm{ND} 0.012 \mathrm{mg} / \mathrm{L}$ 였으며, 제거된 $\mathrm{BDOC}$ 농도범위 는 $0.089 \sim 0.615 \mathrm{mg} / \mathrm{L}$ 였다. 그러나 추가적으로 $0.01 \mathrm{mg} / \mathrm{L}$ 의 $\mathrm{PO}_{4}-\mathrm{P}$ 를 투입한 경우 $\left(\mathrm{PO}_{4}-\mathrm{P}+\mathrm{BAC}\right.$ 와 $\left.\mathrm{PO}_{4}-\mathrm{P}+\mathrm{H}_{2} \mathrm{O}_{2}+\mathrm{BAC}\right)$ 에 $0.011 \sim 0.023 \mathrm{mg} / \mathrm{L}$ 의 $\mathrm{PO}_{4}-\mathrm{P}$ 농도 범위에서 제거된 $\mathrm{BDOC}$ 농 도 범위는 $0.367 \sim 0.798 \mathrm{mg} / \mathrm{L}$ 로 나타났다.

Fig.5에서 볼 수 있듯이 각각의 $\mathrm{BAC}$ 컬럼들에서 평균적 으로 제거된 $\mathrm{BDOC}$ 농도의 경우, control-BAC에서는 0.279 $\mathrm{mg} / \mathrm{L}, \mathrm{H}_{2} \mathrm{O}_{2}+\mathrm{BAC}$ 에서는 $0.336 \mathrm{mg} / \mathrm{L}, \mathrm{PO}_{4}-\mathrm{P}$ 를 첨가한 $\mathrm{PO}_{4}-\mathrm{P}$ $+\mathrm{BAC}$ 와 $\mathrm{PO}_{4}-\mathrm{P}+\mathrm{H}_{2} \mathrm{O}_{2}+\mathrm{BAC}$ 에서는 각각 0.583 과 $0.602 \mathrm{mg} / \mathrm{L}$ 로 나타났다. Control-BAC에 비하여 $\mathrm{H}_{2} \mathrm{O}_{2}+\mathrm{BAC}$ 에서의 평 균 $\mathrm{BDOC}$ 제거율은 $20 \%$ 정도 높게 나타났고, $\mathrm{PO}_{4}-\mathrm{P}+\mathrm{BAC}$ 


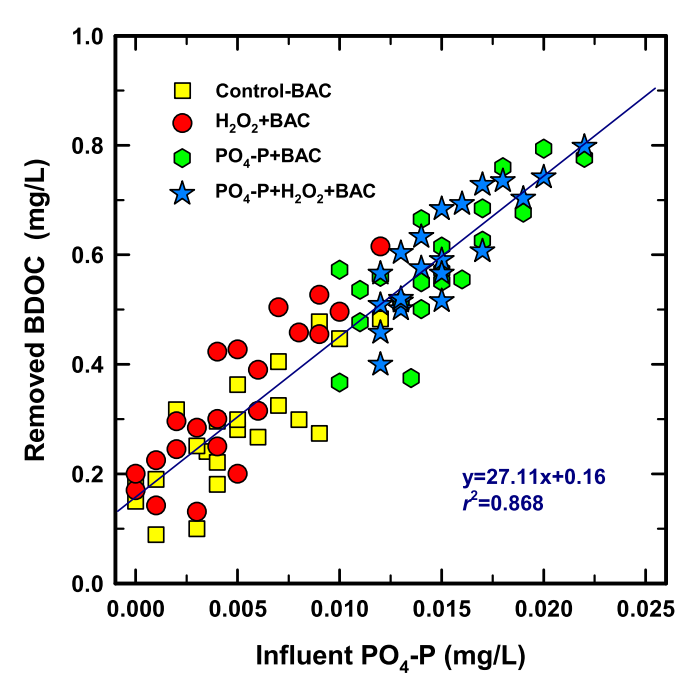

Fig.4. Correlation between biodegradable dissolved organic carbon and $\mathrm{PO}_{4}-\mathrm{P}$ in $\mathrm{BAC}$ columns.

와 $\mathrm{PO}_{4}-\mathrm{P}+\mathrm{H}_{2} \mathrm{O}_{2}+\mathrm{BAC}$ 에서는 각각 $109 \%$ 및 $116 \%$ 정도 높은 것으로 평가되었다.

Nishijima 등 ${ }^{14)}$ 은 DOC 농도가 $9.5 \mathrm{mg} / \mathrm{L}$ 인 유입수에 대해 $\mathrm{PO}_{4}-\mathrm{P}$ 투입 유무에 따른 $\mathrm{BAC}$ 처리 유출수에서의 $\mathrm{DOC}$ 농 도를 평가한 결과, $\mathrm{PO}_{4}-\mathrm{P}$ 를 투입한 $\mathrm{BAC}$ 처리수에서 $\mathrm{DOC}$ 농도는 $3.9 \mathrm{mg} / \mathrm{L}$ (제거율: $59 \%$ )로 나타난 반면 $\mathrm{PO}_{4}-\mathrm{P}$ 를 투 입하지 않은 $\mathrm{BAC}$ 처리수에서의 $\mathrm{DOC}$ 농도는 $8.7 \mathrm{mg} / \mathrm{L}$ (제 거율: $8 \%$ )로 나타나 $\mathrm{PO}_{4}-\mathrm{P}$ 투입에 따른 현저한 $\mathrm{BAC}$ 효율 차이를 보고하였다. 또한, Lauderdale 등의 연구결과 ${ }^{7}$ 에서도 기존 biofilter에 $\mathrm{H}_{2} \mathrm{O}_{2}$ 와 $\mathrm{PO}_{4}-\mathrm{P}$ 를 각각 투입(강화)하여 0.2 $\mathrm{mg} / \mathrm{L}$ 와 $0.35 \mathrm{mg} / \mathrm{L}$ 의 $\mathrm{DOC}$ 가 추가적으로 제거된 것으로 보 고하고 있다. Sang 등의 연구결과 ${ }^{22}$ 에서도 세라믹 다공질 담체를 충진한 biofilter들을 장기간 운전하면서 $\mathrm{PO}_{4}-\mathrm{P}$ 보충 유무에 따른 $\mathrm{TOC}$ 제거율을 평가한 결과, $\mathrm{PO}_{4}-\mathrm{P}$ 을 보충한 biofilter에서의 평균 제거율은 $22 \%$ 27\%, 영양 $\left(\mathrm{PO}_{4}-\mathrm{P}\right)$ 제한 이 있는 biofilter에서는 $17 \%$ 21\%의 TOC 제거율을 나타낸 것으로 보고하고 있다. 그러나 Selbes 등과 과 Noh 등 ${ }^{20)}$ 의 연 구결과에서는 $\mathrm{H}_{2} \mathrm{O}_{2}$ 와 $\mathrm{PO}_{4}-\mathrm{P}$ 를 첨가하여 운전한 경우에도 추가적인 유기물질 제거율의 상승은 관찰되지 않은 것으로 보고하고 있어 본 연구와 상이한 결과를 나타내었다. Selbes 등8)은 biofilter 제거효율에 있어서 다양한 요소들이 biofilter 의 영양염 $\left(\mathrm{PO}_{4}-\mathrm{P}\right)$ 보충 효과를 상쇄시킬 수 있기 때문에 biofilter 최적화를 위한 영양염 보충 전략의 유용성을 명확 히 하기 위한 추가적인 연구의 필요성을 지적하고 있다.

\section{3. 생물막 안정도 평가}

정상 상태에 도달한 biofilter의 생물막에서는 생체량의 성 장 및 감소가 균형을 이룬다. ${ }^{23)}$ 생물막 생체량의 감소요인 으로는 활성 저하로 인한 탈리, 역세척에 따른 마모 및 세포 노화로 인한 사멸 등이 있다. ${ }^{23)}$ 따라서 $\mathrm{BAC}$ 와 같은 biofilter

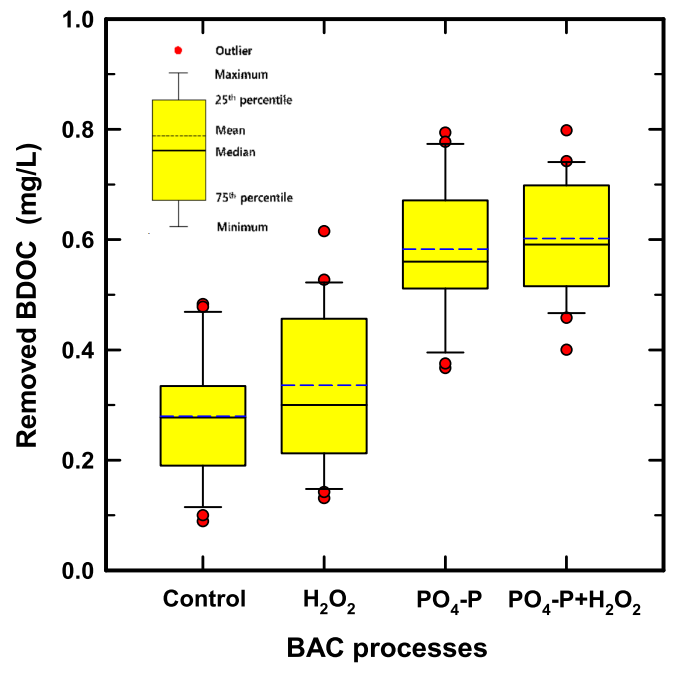

Fig. 5. The removal of $B D O C$ in enhanced $B A C$ processes $(n=24)$.

처리수에서는 생물막에서 탈리된 박테리아들이 검출되고, 이러한 현상은 일반적으로 수질문제로 간주되지는 않는다. ${ }^{8)}$

$\mathrm{Kim}$ 등의 연구결과 ${ }^{24)}$ 에서는 하절기에 비하여 동절기에 $\mathrm{BAC}$ 처리수에서 종속영양성 박테리아 개체수(heterotrophic plate count, HPC)가 증가하였으며, 이를 동절기의 낮은 수 온으로 인한 부착 박테리아들의 활성도 저하에 의한 것으로 보고하고 있다. 수온이 상승함에 따라 $\mathrm{BAC}$ 처리수에서의 $\mathrm{HPC}$ 도 점진적으로 감소하는 것으로 보고하고 있어 생물막 의 탈리현상은 부착 생물막의 생체량의 많고 적음보다는 생 물막 활성도의 높고 낮음에 좌우되는 경향을 나타낸다.

정상상태에 도달한 각각의 $\mathrm{BAC}$ 컬럼들의 유출수를 대상 으로 flow cytometer를 사용하여 총 박테리아 개체수(TCC) 를 분석한 결과를 Fig.6에 나타내었다. Flow cytometer를 이 용한 TCC 분석은 배양 가능한 박테리아뿐만 아니라 배양이 불가능한 박테리아까지 측정이 가능하며, 박테리아의 활성 유무까지 판별된다. Fig.6에서 볼 수 있듯이 4등분된 그림 의 우측 상단 구역은 염색된 비활성(dead) 박테리아 개체 를 청색 점으로 나타내고 있으며, 우측 하단 구역은 염색 된 활성(live) 박테리아 개체를 청색 점으로 나타내고 있다. Control-BAC에 비하여 $\mathrm{H}_{2} \mathrm{O}_{2}$ 와 $\mathrm{PO}_{4}-\mathrm{P}$ 를 투입한 강화 $\mathrm{BAC}$ 에서 탈리된 박테리아 개체수가 적었으며, 또한, 탈리된 박 테리아의 대부분이 활성 박테리아로 평가되었다(Fig. 6).

정상상태에 도달한 이후, $\mathrm{BAC}$ 처리수 중의 $\mathrm{TCC}$ 를 월 4회 분석(총 24회)하여 평균한 결과를 Fig.7에 나타내었다. Fig. 7에서 볼 수 있듯이 control-BAC 처리수의 $\mathrm{TCC}$ 는 평균 $41.7 \times 10^{6}$ cells $/ \mathrm{mL}$ 로 나타났다. 또한, $\mathrm{H}_{2} \mathrm{O}_{2}+\mathrm{BAC}, \mathrm{PO}_{4}-\mathrm{P}+$ $\mathrm{BAC}$ 및 $\mathrm{PO}_{4}-\mathrm{P}+\mathrm{H}_{2} \mathrm{O}_{2}+\mathrm{BAC}$ 처리수의 경우는 평균 $21.2 \times 10^{6}$ cells $/ \mathrm{mL}, 13.7 \times 10^{6}$ cells $/ \mathrm{mL}$ 및 $6.3 \times 10^{6}$ cells $/ \mathrm{mL}$ 로 control$\mathrm{BAC}$ 에 비해 각각 $49 \%, 67 \%$ 및 $85 \%$ 정도 감소되었다.

또한, $\mathrm{TCC}$ 를 구성하는 활성 및 비활성 박테리아의 구성 비 


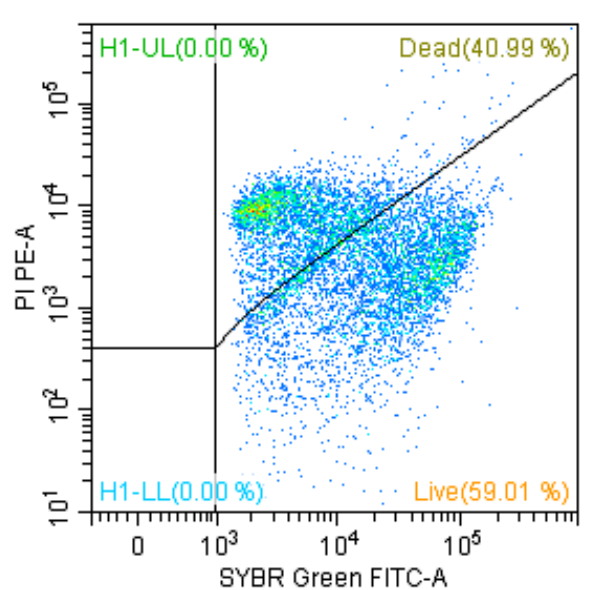

(a) Control-BAC

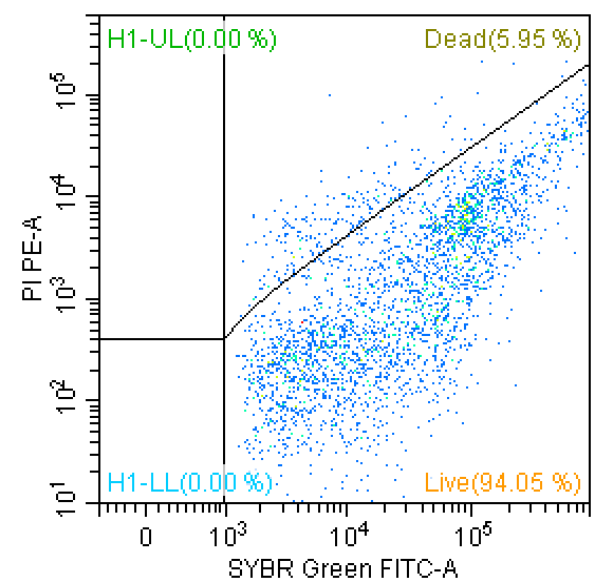

(c) $\mathrm{PO}_{4}-\mathrm{P}+\mathrm{BAC}$

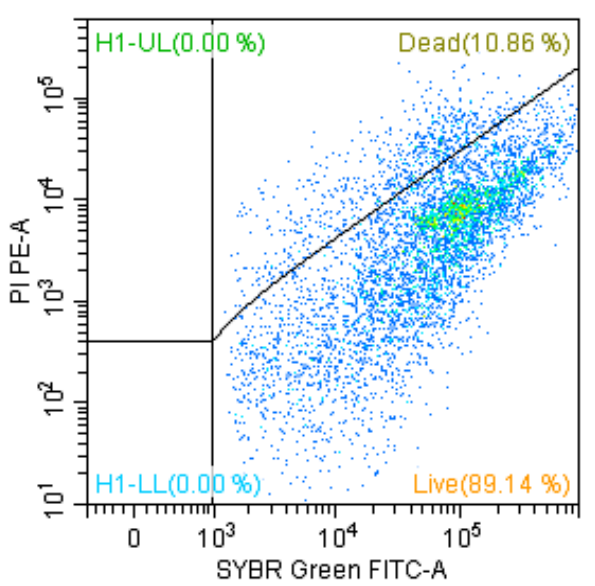

(b) $\mathrm{H}_{2} \mathrm{O}_{2}+\mathrm{BAC}$

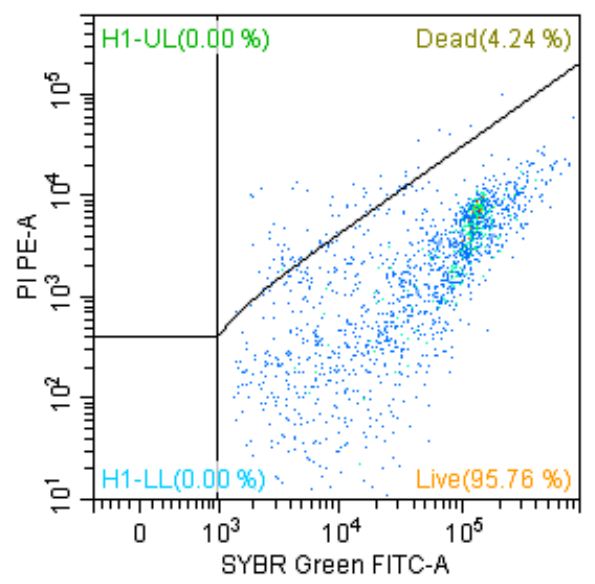

(d) $\mathrm{PO}_{4}-\mathrm{P}+\mathrm{H}_{2} \mathrm{O}_{2}+\mathrm{BAC}$

Fig. 6. Dot plot of TCC in enhanced BAC effluents using flow cytometric analysis (upper right area : dead cell, lower right area : live cell).

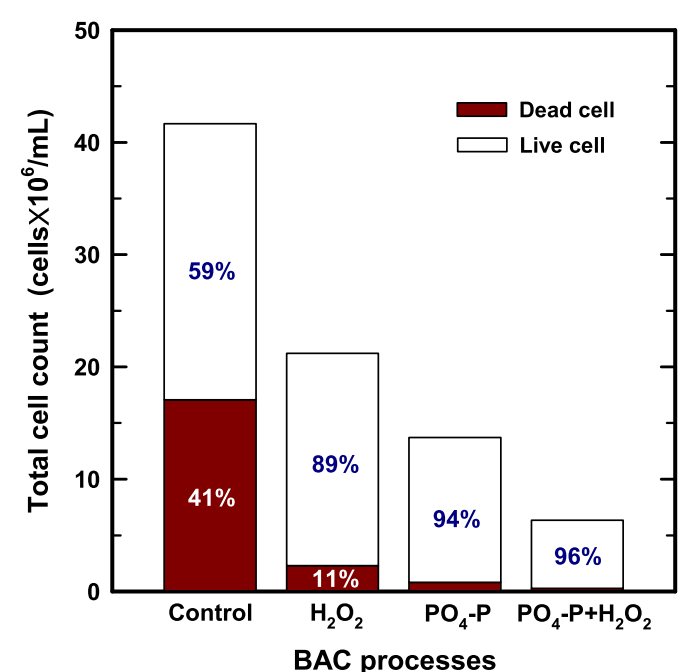

Fig. 7. Comparison of total cell counts (TCC) in enhanced BAC effluents and composition ratio of live cells and deal cells $(n=24)$.

율을 살펴보면 control-BAC에서는 평균적으로 활성 박테리 아가 $59 \%$, 비활성 박테리아가 $41 \%$ 로 나타났으나 강화 BAC
들에서는 활성 박테리아의 비율이 $89 \%$ $96 \%$ 로 매우 높게 나 타났다. 이러한 결과는 강화 $\mathrm{BAC}$ 들에서는 부착 생물막을 구성하는 박테리아의 대부분이 활성 박테리아로 구성되어 져 있다는 것을 의미하며, Table2에서 볼 수 있듯이 강화된 $\mathrm{BAC}$ 들의 생물막 활성도가 기존 $\mathrm{BAC}$ (control-BAC)에 비하 여 높기 때문에 여층 내에서 수류의 전단력으로 인해 탈리되 는 박테리아들의 개체수도 적은 것으로 평가되었다.

\section{4. 결론}

인 $\left(\mathrm{PO}_{4}-\mathrm{P}\right)$ 과 과산화수소 $\left(\mathrm{H}_{2} \mathrm{O}_{2}\right)$ 를 투입한 강화 $\mathrm{BAC}$ 공정 에서의 부착 생물막의 특성과 $\mathrm{BDOC}$ 제거능을 기존의 $\mathrm{BAC}$ 공정과 동일한 운전조건에서 비교·평가하여 다음과 같은 결론을 얻을 수 있었다.

1) $\mathrm{BAC}$ 강화 조건에 따른 생물막 회복능을 평가한 결과, $\mathrm{H}_{2} \mathrm{O}_{2}$ 를 투입한 강화 $\mathrm{BAC}$ 에서는 기존 $\mathrm{BAC}$ 와 비교하 여 생체량 회복율에 차이는 없었으며, $\mathrm{PO}_{4}-\mathrm{P}$ 를 투입한 강화 $\mathrm{BAC}$ 에서는 기존 $\mathrm{BAC}$ 에 비해 생체량의 빠른 회 복율을 나타내었다. 
2) 정상상태 도달 이후의 생물막 특성 평가에서 지속적으 로 $\mathrm{PO}_{4} \mathrm{-P}$ 를 투입한 강화 $\mathrm{BAC}$ 에서는 기존 $\mathrm{BAC}$ 에 비해 생체량과 활성도가 각각 $20 \sim 86 \%$ 및 7 14\% 정도 증가 하였으나 $\mathrm{H}_{2} \mathrm{O}_{2}$ 를 투입한 강화 $\mathrm{BAC}$ 에서는 활성도만 $3 \sim 11 \%$ 정도 증대되었다.

3) $\mathrm{BDOC}$ 제거율 평가에서는 기존 $\mathrm{BAC}$ 에 비하여 강화 $\mathrm{BAC}$ 에서의 $\mathrm{BDOC}$ 제거율이 증대되었으며, 특히, $\mathrm{PO}_{4}-\mathrm{P}$ 를 투 입한 강화 $\mathrm{BAC}$ 에서 $\mathrm{BDOC}$ 제거율이 $100 \%$ 이상 증대되 었다.

4) 생물막에서의 박테리아 탈리율로 평가한 생물막 안정도 는 기존 $\mathrm{BAC}$ 에 비하여 강화 $\mathrm{BAC}$ 에서 탈리율이 49 85\% 저감되었으며, $\mathrm{PO}_{4}-\mathrm{P}$ 를 투입한 강화 $\mathrm{BAC}$ 에서 높은 생물 막 안정도(낮은 박테리아 탈리율)를 나타내었다.

\section{References}

1. H. J. Son, S. J. Yoo, J. S. Roh, P. J. Yoo, Biological activated carbon (BAC) process in water treatment, J. Korean Soc. Environ. Eng., 31(4), 308-323(2009).

2. C. Liu, C. I. Olivares, A. J. Pinto, C. V. Lauderdale, J. Brown, M. Selbes, T. Karanfil, The control of disinfection byproducts and their precursors in biologically active filtration processes, Water Res., 124, 630-653(2017).

3. D. M. Son, H. J. Son, H. J. Lee, L. S. Kang, Removal of geosmin and 2-MIB using biological activated carbon process, J. Korean Soc. Water Wastewater, 23(2), 189-198 (2009).

4. J. Fu, W. N. Lee, C. Coleman, K. Nowack, J. Carter, C. H. Huang, Removal of pharmaceuticals and personal care products by two-stage biofiltration for drinking water treatment, Sci. Total Environ., 664, 240-248(2019).

5. H. J. Son, H. K. Park, S. A. Lee, E. Y. Jung, C. W. Jung, The characteristics of microbial community for biological activated carbon in water treatment plant, J. Korean Soc. Environ. Eng., 27(12), 1311-1320(2005).

6. N. Moona, U. J. Wünsch, M. Bondelind, O. Bergstedt, T. Sapmaz, T. J. R. Pettersson, K. R. Murphy, Temperaturedependent mechanisms of DOM removal by biological activated carbon filters, Environ. Sci.: Water Res. Technol., 5(12), 2232-2241(2019).

7. C. Lauderdale, P. Chadik, M. J. Kirisits, J. Brown, Engineered biofiltration: enhanced biofilter performance through nutrient and peroxide addition, J.-Am. Water Works Assoc., 104(5), E298-E309(2012).

8. M. Selbes, J. Amburgey, C. Peeler, A. Alansari, T. Karanfil, Evaluation of seasonal performance of conventional and phosphate-amended biofilters, J.-Am. Water Works Assoc., 108(10), E523-E532(2016).

9. S, E. Keithley, M. J. Kirisits, Enzyme-identified phosphorus limitation linked to more rapid headloss accumulation in drinking water biofilters, Environ. Sci. Technol., 53(4), 2027-2035(2019).
10. M. W. LeChevallier, W. Schulz, R. G. Lee, Bacterial nutrients in drinking water, Appl. Environ. Microbiol., 57(3), 857-862(1991).

11. D. L. Pardieck, E. J. Bouwer, A, T. Stone, Hydrogen peroxide use to increase oxidant capacity for in situ bioremediation of contaminated soils and aquifers: a review, J. Contaminant Hydrol., 9(3), 221-242(1992).

12. B. E. Christensen, H. N. Trønnes, K. Vollan, O. Smidsrød, R. Bakke, Biofilm removal by low concentration of hydrogen peroxide, Biofouling, 2(2), 165-175(1990).

13. E. Neyens, J. Baeyens, M. Weemaes, B. De Heyder, Advanced biosolids treatment using $\mathrm{H}_{2} \mathrm{O}_{2}$ oxidation, Environ. Eng. Sci., 19(1), 27-35(2002).

14. W. Nishijima, E. Shoto, M. Okada, Improvement of biodegradation of organic substance by addition of phosphorus in biological activated carbon, Water Sci. Technol., 36(12), 251-257(1997).

15. H. J. Son, C. W. Jung, Y. I. Choi, L. S. Kang, Formation characteristics of $\mathrm{BDOC}_{\text {rapid }}$ and $\mathrm{BDOC}_{\text {slow }}$ by ozonation, J. Korean Soc. Environ. Eng., 28(12), 1274-1279(2006).

16. S. Velten, F. Hammes, M. Boller, T. E. Egli, Rapid and direct estimation of active biomass on granular activated carbon through adenosine tri-phosphate (ATP) determination, Water Res., 41(9), 1973-1983(2007).

17. H. J. Son, J. K. Lee, S. G. Kim, H. K. Park, E. Y. Jung, Removal characteristics of geosmin and MIB in BAC process: biodegradation and adsorption, J. Korean Soc. Environ. Eng., 39(6), 318-324(2017).

18. P. Servais, G. Billen, M. C. Hascoët, Determination of the biodegradable fraction of dissolved organic matter in waters, Water Res., 21(4), 445-450(1987).

19. S. Goel, R. M. Hozalski, E. J. Bouwer, Biodegradation of NOM: effect of NOM source and ozone dose, J.-Am. Water Works Assoc., 87(1), 90-105(1995).

20. J. H. Noh, S. H. Yoo, H. Son, K. E. Fish, I. Douterelo, S. $\mathrm{K}$. Maeng, Effects of phosphate and hydrogen peroxide on the performance of a biological activated carbon filter for enhanced biofiltration, J. Hazard. Mater., 388, 121778(2020).

21. O. D. Basu, S. Dhawan, K. Black, Applications of biofiltration in drinking water treatment - a review, J. Chem. Technol. Biotechnol., 91(3), 585-595(2016).

22. J. Sang, X. Zhang, L. Li, Z. Wang, Improvement of organics removal by bio-ceramic filtration of raw water with addition of phosphorus, Water Res., 37(19), 4711-4718(2003).

23. M. S. Siddiqui, G. L. Amy, B. D. Murphy, Ozone enhanced removal of natural organic matter from drinking water sources, Water Res., 31(12), 3098-3106(1997).

24. S. G. Kim, H. G. Park, H. J. Son, H. S. Yoom, D. C. Ryu, Evaluation of influence factors for determination of proper backwashing time of biological activated carbon (BAC) process in drinking water treatment process, J. Environ. Sci. Int., 24(12), 1551-1558(2015). 


\section{Authors}

\section{Heejong Son}

Water Quality Institute, Busan Water Authority, Researcher, ORCID(1) 0000-0002-7950-8223

\section{Eun-Young Jung}

Water Quality Institute, Busan Water Authority, Researcher, ORCID(D) 0000-0003-4053-7585

\section{Hoon-Sik Yoom}

Water Quality Institute, Busan Water Authority, Researcher, ORCID(D) 0000-0002-4736-7235

\section{Sang-Goo Kim}

Water Quality Institute, Busan Water Authority, Researcher, ORCID(10) 0000-0003-4977-8684

\section{Sung Kyu Maeng}

Department of Civil and Environmental Engineering, Sejong University, Professor, ORCID (ㄷ) 0000-0001-6257-1739 